\title{
Performance Optimization of Anchovy Fish Processing Industry Cluster through Value Chain Analysis on Pulau Pasaran
}

\author{
Nanda Alifia Putri ${ }^{1,}$ Raden Isma Anggraini ${ }^{1}$, Mohammad Syamsul Maarif \\ ${ }^{1}$ School of Business IPB University Bogor, Indonesia \\ "Corresponding author. Email: nalifiaputri@gmail.com
}

\begin{abstract}
Pulau Pasaran is known as the main centre of salted anchovy fish production in Bandar Lampung City which have capabilities to produce twenty to thirty tons of salted anchovy fish a day and will be marketed to several region on Java Island and Sumatera Island. This study is proposed to (1) identify the business process of the anchovy fish processing industry at Pulau Pasaran, (2) analyise the performance of the anchovy fish processing industry at Pulau Pasaran, and (3) formulate better strategy that can be applied in optimising performance of the anchovy fish processing industry at Pulau Pasaran. The technique of determining respondents using purposive sampling. The number of sampling in this study was 18 respondents namely anchovy processing business owners, crafter, fishers, experts in the field of fisheries, and community group leaders in the area of Pasaran Island. This study using Porter's Value chain analysis combined with Structure, Conduct, Performance (SCP) analysis and also SWOT Analysis to see any gaps between the real conditions and the desired conditions of the existing performance on Pasaran Island. The result showed that the performance of the anchovy processing cluster industry in Pulau Pasaran was not optimal because the industrial owner did not have a bargaining position in determining prices and product quality standards that were not optimal. The formulated strategies are create diversified products and improve product quality standard to optimised performance on Pulau Pasaran.
\end{abstract}

Keywords - industry performance, quality standardization, value chain analysis

\section{INTRODUCTION}

Indonesia is a maritime country where most of its territory is oceans and its land area is smaller than the area of its oceans. This can be seen from the coastline in Indonesia which reaches $\pm 108,000 \mathrm{~km}$ and makes Indonesia ranked second only to Canada as the country with the longest coastline in the world. This strength is the great potential to advance the Indonesian economy [1]. In addition, the fishery sector in Indonesia is a sector that contributes a lot to the growth rate of Indonesia's Gross Domestic Product (GDP). Figure 1 shows that the amount of fishery production in Indonesia has increased significantly from 2011 to 2016.

The potential of Indonesian fishery resources is also spread to various provinces in Indonesia, one of which is Lampung Province. Based on the Decree of the Minister of Marine Affairs and Fisheries of the Republic of Indonesia No KEP 18/MEN/2011 dated April 5 2011, Lampung Province is one of the minapolitan area in Indonesia. Minapolitan area is a part of the region that has the main function of the economy consisting of production centers, processing, marketing of fishery commodities, service services, and or other supporting activities [1].

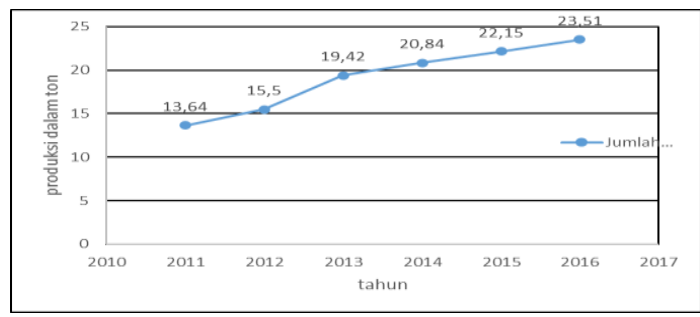

Fig 1. Total Fishery Production in Indonesia 2011-2016

Lampung province is one of the areas that has a strategic cross-sea communication line, as well as a strategic position. The condition of Lampung area that is strategic and adjacent to the sea coast makes Lampung area can produce greater production of capture fisheries compared to other regions. Business opportunities in the fishery sector have good prospects. Fish is a product 
that is very easy to decay so as to avoid damage and decay can be done various processing such as salting or salting. One of the fish processing centers in Lampung is located on Pasaran Island. Pasaran Island is an island in Teluk Betung Barat District, Bandar Lampung City, Lampung Province. Pasaran Island is known as the main center of salted anchovy production that is able to produce twenty to thirty tons of salted anchovy every day that will be marketed to several regions in Java Island and some areas on the island of Sumatera. The raw material of anchovy is obtained from fishermen. Anchovy that have been purchased from fishermen will go through the process of processing with processed salted anchovy. The target market of this industry is not only the domestic market but also to foreign countries. However, there is still a lack from this industry where fish processing is still lacking in providing added value to its products.

Salted anchovy fish products can be added in terms of packaging, flavor innovation or giving a brand that can be known more widely for the typical salted anchovy from Pasaran Island. The value added of a product can be improved through value chain analysis. In addition, in terms of internal industry is perceived still less optimal performance in the industry so that the center of this Pasaran Island has not been able to determine a competitive price. This non optimal performance can be caused by the structure of the industry or the behavior of actors in the industry.

Research conducted by [3] relates to the anchovy processing industry on Pasaran Island. The research conducted by [4] is about industrial performance in anchovy processing on Pasaran Island. Therefore, this study intends to analyze efforts to optimize the performance of salted anchovy processing through Porter's Value Chain Analysis combined with Structure, Conduct, Performance (SCP) analysis to see any gaps between the real conditions and the desired conditions of the existing performance on Pasaran Island.

\section{MATERIALS AND METHODS}

This research was conducted at the end of December 2019 to January 2020 in Pasar Island, Bandar Lampung City, Lampung Province. The implementation of research is carried out through several stages, namely the stage of preparation, data collection, processing, data analysis and data reporting. This research was using descriptive methods of primary and secondary data. Primary data is obtained from business process observation and in-depth interview. Secondary data is obtained from a variety of relevant sources.

The technique of determining respondents using one of the non-probability sampling methods (non-random / purposeful sampling) is purposive sampling. The population in this study was 60 business owners, and the leeway percentage used was $20 \%$ (because the population was small), so that the number of sampling in this study was 18 respondents. Respondents of this study include anchovy processing business owners, crafter, fishers, experts in the field of fisheries, and community group leaders in the area of Pasaran Island.

Respondents were drawn from each head of the processing and marketing group (poklahsar) in the anchovy processing industry cluster on Pasaran Island. Furthermore, the snowball sampling method is used to determine the next respondent. Snowball sampling is carried out by each poklahsar leader and recommends his group members who are still active in the anchovy processing business on Pasaran Island. Respondents needed in this study consisted of internal actors from the anchovy processing industry who have knowledge of the industry and have the authority to formulate and implement strategies. The actors who play a role in this industry are business owners, craftsmen, and fishermen. External parties consist of experts such as academics, government, and professional practitioners. As many as nine experts in the fishing industry are needed to become respondents from external parties. The purpose of having an external party is to determine the overall industrial environment and validate the strategies formulated to optimize performance for experts in the industry.

The data analysis technique used is descriptive qualitative analysis. The data processing and analysis techniques in this study include several stages, namely (1) an initial description of the industry, (2) the observation of the field study business process directly observing the business processes that exist in the industry starting from the procurement of raw materials to the marketing process of the industrial products, 3) mapping each business process into the value chain using Porter's Value Chain Analysis (4) Structure, Conduct, Perfirmance (SCP) analysis to analyze the performance of the anchovy processing industry, (5) recommending a new strategy and value chain mapping using SWOT analysis.

\section{A. Value Chain Analysis}

Value chain analysis is a process in which a company identifies key activities and assistance that adds value to the product. Value chain analysis can be used as one of the cost management analysis tools for strategic decision making in the face of increasingly tight business competition. Decision to determine which competitive strategy to apply, whether using strategy: low cost or differentiation [5]. Value chain analysis is a tool analysis that aims to analyze the company's internal business process activities. One of the value chain analysis used by many companies is Porter's Value Chain Analysis. Porter's Value Chain Analysis focuses on the system, and how inputs are converted into outputs purchased by consumers. Porter distinguishes two categories of processes: main activities and supporting activities. Porter's Value Chain Analysis model can be seen in Fig 2. 


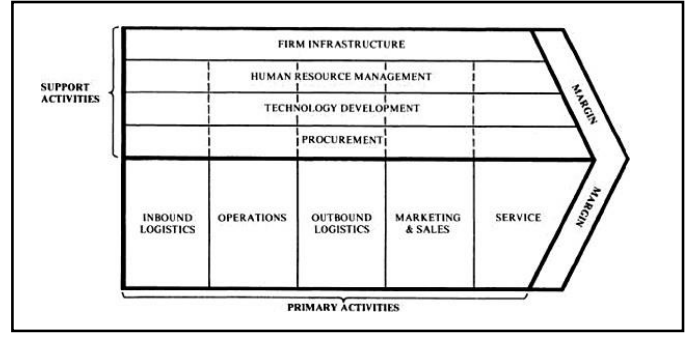

Fig 2. Porter's Value Chain Analysis Model

\section{B. Structure-Conduct-Performance Analysis}

According to industry organization theory, there is an SCP or Structure-Conduct-Performance concept. The theory explains that the performance of an industry is basically heavily influenced by the structure of the market. The market structure indicates market attributes that influence the nature of the competition process. Elements of the market structure include: concentration, product differentiation, barriers to entry into the market, cost structure and level of government regulation. The structure of the market is considered important, because it will determine the behavior and strategy of the company in an industry and then the behavior will affect performance [6]. The simplest of the three variables in SCP Analysis is a linear relationship where the structure can influence behavior and then behavior affects performance. Structure (structure)of an industry will determine how the behavior of industry players (conduct)that ultimately determines the performance (performance) of the industry, as seen in Figure 3.

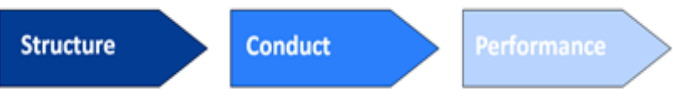

Fig 3. SCP Analysis Linear Relationship

\section{SWOT Analysis}

SWOT analysis is a strategic planning method to evaluate the factors that influence in achieving goals, namely strengths, weaknesses, opportunities, and threats. According to [7], the definition of SWOT analysis is part of the company's strategic management process that aims to identify the company's key strengths and weaknesses. These weaknesses and strengths are compared to external opportunities and threats as the basis for producing a variety of alternative strategies.

\section{RESULTS}

\section{A. Pulau Pasaran}

Pasar Island is a small reclaimed island with a distance of \pm 500 meters from the shore of Bandar Lampung city that can be reached by boat for approximately five minutes or it can also be through an access bridge made by the Government of Bandar Lampung. The area of this island \pm to 13 hectares with a population of $\pm 1,300$ inhabitants. Almost all of its residents have a livelihood as workers / processing dried fish from upstream to downstream that has been done for generations. Residents of Pasar Island in general have been in the field of fish processing for \pm 50 years, so that even with simple equipment they can produce dried anchovy fish with good quality.

\section{B. Value Chain Analysis}

\section{1) Actor Identification}

In the value chain analysis on the processing of anchovy fish on Pasaran Island there are four actors who play a role, business owners, anchovy craftsmen, fishermen, and collectors. Each actor has their own role. Every actor has a strong relationship if none of the actors will have an impact on the business process. Value chain in the processing of anchovy fish starts from the fishermen chart that sell raw materials, permanent workers who process raw materials, sorting based on the type of fish by craftsmen, packaging process and lastly to the collector who will market the product out of Pasaran Island. This data has increased or decreased every year because at certain times there are business that have to vacuum because of lack of capital or switch to fish processing businesses in other areas. Based on the results of the interview to the Chairman of RT on Pasaran Island, there are 60 business owners in Pasaran Island.

2) Identification of Primary Activities and Supporting Activities

The business processes in the industry cluster of salted anchovy fish processing industry include the purchase of raw materials to fishermen, boiling on board, drying on land, sorting process by craftsmen, packing process and product marketing. The process of processing dried fish begins with the process of finding raw materials. Pelele fishermen, the name for the crew of the fish processing business on Pasar Island started its activities around 16.00 to go down to sea and look for charts that are catching fish or that have been lifted. Then the processor negotiates with the chart fishermen to buy fish that have generally been stocked in a sunken. After the price of wet fish is agreed, the processor will immediately boil the fresh wet fish in the ship in which the boiler is attached. This process was special in the processing of fish on Pasaran Island because with the process of directly cooking in the sea the fish produced will be better quality and visually will qualify for export. The value chain analysis can be seen in Fig 4 . 


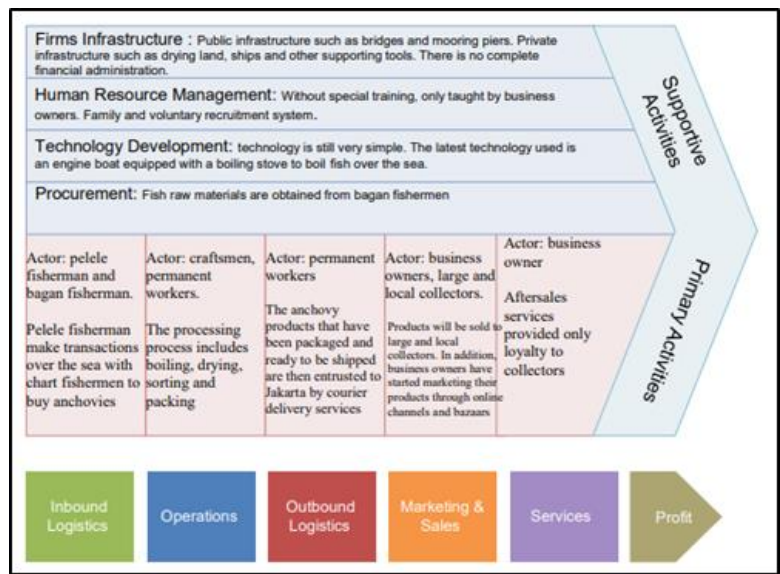

Fig 4. Value Chain Analysis of Pasaran Island

\section{Industry Performance Analysis (SCP Analysis) 1) Structure}

In the analysis of market structure can be seen from the elements of the market namely the number of sellers, the ability to determine prices, barriers in and out of the market, the nature of products, and market information. Analysis of market structure in this study aims to find out whether the salted anchovy market on Pasar Island tends to lead to perfect competition market or imperfect competition market that will affect market behavior and performance.

Based on the results of the interview, the number of processors on Pasaran Island as many as 60 processing businesses. The type of products sold in the cluster of fish processing industry on Pasar Island is homogeneous because the fish sold is anchoin. Although the goods sold are homogeneous there is a differentiation of products between processors. In addition, there is competition between groups of processors and marketers (poklahsar) and there have started to be processors who add brands to their processed products. Barriers to entering the industry can be said to be nonexisting because every processor on Pasaran Island who wants to start a processing business can be free to enter and exit.

Furthermore, market information is open so that no information is only owned by one party. Monopolistic market is a market with many manufacturers in producing the same goods but each of these goods has differences in several aspects. The existence of product differentiation creates market power and differences for some business owners so that the type of market in the cluster of anchos processing industry on Pasar Island is a monopolistic competition market. Table 1 shows the results of analysis with market elements to determine the structure of the market.
TABLE 1. MARKET STRUCTURE IN PASARAN ISLAND

\begin{tabular}{|l|l|}
\hline \multicolumn{1}{|c|}{ Actors } & \multicolumn{1}{|c|}{$\begin{array}{c}\text { Sales and Marketing } \\
\text { Purposes }\end{array}$} \\
\hline Number of sellers & 60 sellers \\
\hline Ability to determine & Easy \\
\hline Types of product sold & Similar but differentiation \\
\hline Barriers to entry market & Nothing \\
\hline Market information & Open \\
\hline Conclussion: Included in the monopolistic market type \\
\hline
\end{tabular}

\section{2) Conduct}

In this study, market behavior is determined based on the mechanism of pricing and distribution channels of the industry. In the pricing process, there is no detailed calculation from fish processors on Pasaran Island in determining how much the fixed cost of production, variable cost, and selling price. Pricing is only estimated based on the purchase price on the fishing chart, the quality of the fish and the current season. If the quality of fish is good, then the selling price will increase. However, if the quality of fish is good and fish stocks are abundant, it is not uncommon for the selling price of the product to fall.

In addition, the daily profits earned by processors are uncertain Anchovy fish processing industry cluster on Pasaran Island does not have financial records so the calculation of cost, revenue, and profit is only limited to the estimate of each business owners. For example, business owner processors estimate that if the price of fish is rising, good quality and stable market demand of each processor will produce as much as three quintals and get daily profits varying between 5-10 million rupiah. Table 2 shows the behavior of each actor in the anchovy fish processing industry on Pasaran Island.

TABLE 2. THE BEHAVIOR OF EACH ACTORS IN THE INDUSTRY

\begin{tabular}{|c|l|l|l|l|}
\hline No & Actors & $\begin{array}{c}\text { Sales and } \\
\text { Marketing } \\
\text { Purposes }\end{array}$ & \multicolumn{1}{|c|}{$\begin{array}{c}\text { Pricing } \\
\text { process }\end{array}$} & \multicolumn{1}{|c|}{$\begin{array}{c}\text { Payment } \\
\text { System }\end{array}$} \\
\hline 1 & Fisherman & $\begin{array}{l}\text { Processing } \\
\text { business } \\
\text { owner }\end{array}$ & Bargaining & Cash \\
\hline 2 & $\begin{array}{l}\text { Business } \\
\text { owners }\end{array}$ & $\begin{array}{l}\text { Other } \\
\text { business } \\
\text { owners }\end{array}$ & $\begin{array}{l}\text { Determined } \\
\text { by business } \\
\text { owner }\end{array}$ & Cash \\
\hline 3 & $\begin{array}{l}\text { Business } \\
\text { owners }\end{array}$ & Retailers & $\begin{array}{l}\text { Determined } \\
\text { by business } \\
\text { owner }\end{array}$ & Cash \\
\hline 4 & $\begin{array}{l}\text { Business } \\
\text { owners }\end{array}$ & $\begin{array}{l}\text { Small } \\
\text { collectors }\end{array}$ & Bargaining & $\begin{array}{l}\text { Cash / } \\
\text { payment } \\
\text { letter }\end{array}$ \\
\hline 5 & $\begin{array}{l}\text { Business } \\
\text { owners }\end{array}$ & $\begin{array}{l}\text { Big } \\
\text { collectors }\end{array}$ & $\begin{array}{l}\text { Determined } \\
\text { by big } \\
\text { collectors }\end{array}$ & $\begin{array}{l}\text { Cash/ } \\
\text { payment } \\
\text { letter }\end{array}$ \\
\hline
\end{tabular}

3) Performance

Market performance can be seen from the analysis of sales margin in the cluster of anchovy fish processing industry on Pasaran Island. The results of value chain 
margin analysis showed that large collectors have greater sales margin compared to processors and small collectors. The margin obtained by a large steamer on anchoce jenis rice anchoce is Rp35 000 compared to dengan processor that is Rp32 000 and a small steamer of Rp5 000. The margin analysis can be seen in Table 3.

TABLE 3. MARGIN ANALYSIS

\begin{tabular}{|l|r|r|r|r|r|}
\hline \multirow{2}{*}{ Actor } & \multicolumn{5}{|c|}{ Description (Rp/Kg) } \\
\cline { 2 - 6 } & Price & Cost & Margin & $\begin{array}{c}\text { Seling } \\
\text { Price }\end{array}$ & Margin \\
\hline Fisherman & - & - & - & 53.000 & - \\
\hline Processor & 53.000 & 15.000 & 17.000 & 85.000 & 32.000 \\
\hline $\begin{array}{l}\text { Small } \\
\text { Collector }\end{array}$ & 85.000 & 1.000 & 4.000 & 90.000 & 5.000 \\
\hline $\begin{array}{l}\text { Big } \\
\text { Collector }\end{array}$ & 85.000 & 500 & 34.500 & 120.000 & 35.000 \\
\hline Consumer & 120.000 & - & - & & - \\
\hline
\end{tabular}

\section{SWOT Analysis}

Fig. 5 shows the results of identifying strengths, weaknesses, opportunities, and threats and the arrangement of strategies in dealing with these strengths, weaknesses, opportunities, and threats.

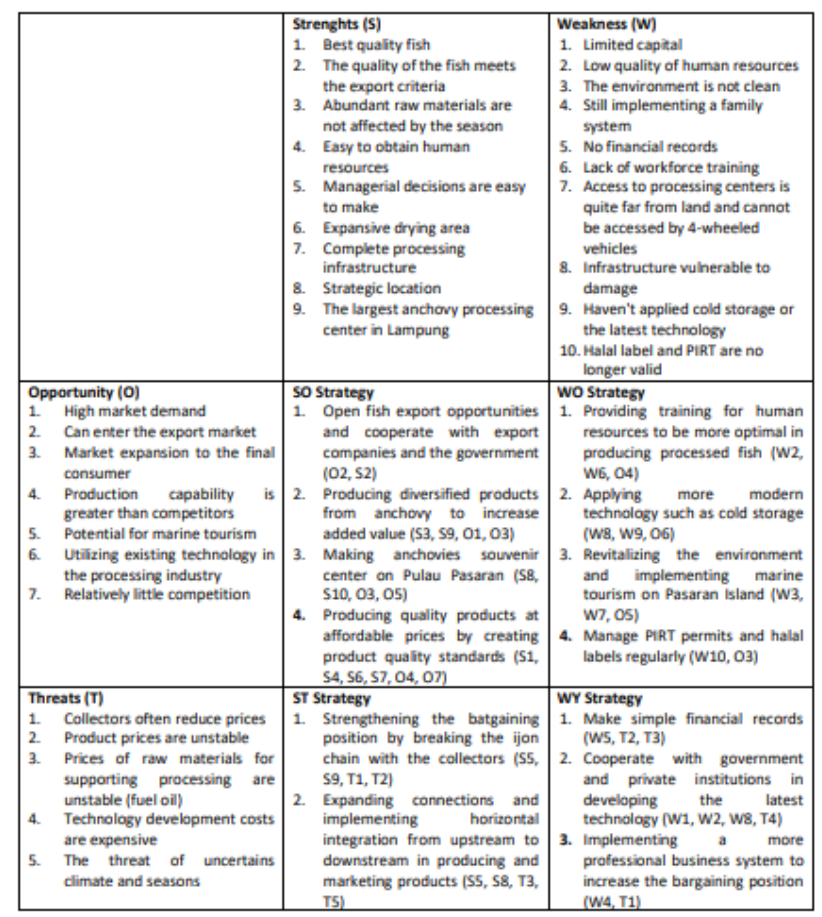

Fig 5. SWOT Analysis

\section{E. $\quad$ Strategy Formulation}

Based on the results of SWOT analysis and validation results to expert respondents obtained the following strategy formulation:

\section{1) Product Strategy}

This sub strategy is related to product development, quality improvement, and matters related to quality and product certification. The product strategies include:
- Producing diversified products from Anchovy fish such as anchovy in cans, and other processed products to increase the value added of the product.

- Conducting product quality tests such as sensory test analysis, total plate numbers, water content, salt and formalin content in processed products on Pasaran Island.

- Creating standardization of production quality in the form of Standard Operational processor does not have high bargaining power in determining the price to the collector.

- Update processing technology by adding storage technology and technology in the drying process.

- Take care of periodic product certifications such as PIRT Permits, Halal Certificates, and export product certifications.

\section{1) Marketing Strategies}

This marketing sub-strategy covers how processors can expand the market and connections so that their products can be marketed nationally and internationally. These strategies include:

- In cooperation with government agencies and export companies to open export opportunities

- Revitalizing the environment and implementing marine tourism in the form of anchovy fish processing education on Pasaran Island.

- Marketing products to local retail such as Chandra Store, Hero, and others.

- Processed products and diversified products are marketed to every souvenir center typical of Lampung by providing more attractive brands such as "Ikan Teri Siger".

- Applying the latest packaging technology to attract consumers in aesthetic value to improve product commercialization.

- Strengthen the bargaining position by cooperating with large collectors to reduce the existing of ijon chain.

\section{3) Human Resource Development Strategy}

In the substrategic human resources development there are several strategies regarding the training needed to improve the skills of actors in the Pasar Island fish processing industry cluster including:

- Providing training to business owner processors and workers in terms of financial recording for MSMEs and capital, as well as digital marketing for MSMEs.

- Re-establish mina karya bahari cooperation with professional development under the guidance of 
the Department of Marine Affairs and Fisheries Bandar Lampung.

- Hold regular meetings between processing groups and marketers in discussing market development to be able to enter the international market and meet international standards.

The new strategy is then mapped into the new value chain as in Fig 6. This new value chain shows the desired condition that should be done by the anchovy fish processing industry cluster on Pasaran Island in order to achieve optimal performance.

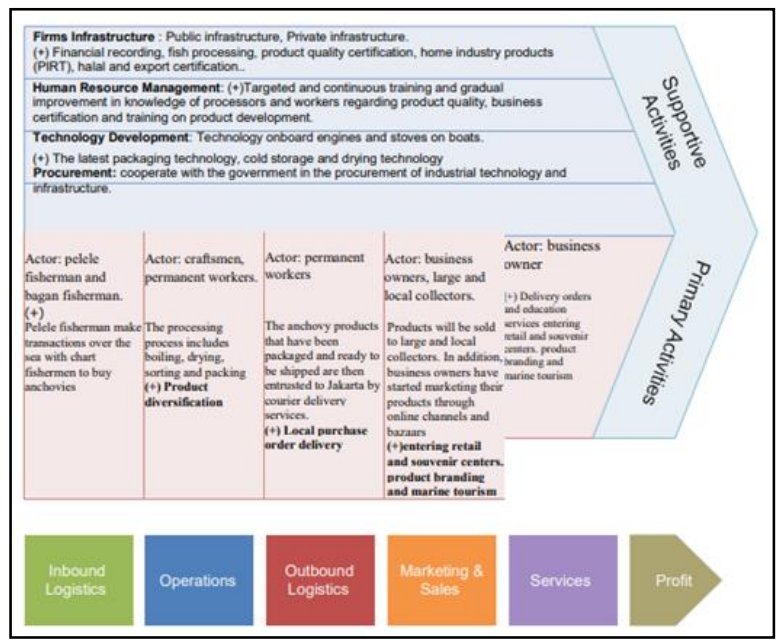

Fig 6 A new value chain for the anchovy processing industry cluster on Pasaran Island

\section{Managerial Implications}

The new strategy that has been formulated will have an impact on the behavior of actors in the value chain on Pasar Island. Therefore, good cooperation is needed between the government, private parties, and internal actors (processors and workers) as well as external actors (fishermen and collectors) in implementing strategies to optimize the performance of the fish processing industry cluster on Pasar Island.

\section{CONCLUSION}

The value chain of anchovy processing on Pasar Island generally involves five main actors, namely business owners, permanent workers, craftsmen, fishermen, and collectors. Broadly speaking, business processes in the cluster of salted anchovy processing industry include the purchase of raw materials to fishermen, boiling on board, drying on land, sorting process by craftsmen, packing process and product marketing.

The structure of the anchovy fish processing market on Pasar Island is a monopolistic market structure. The behavior of the industry is determined by the behavior of each actor in the value chain. The mechanism of determining the selling price to the steamer in the anchovy processing industry cluster on Pasar Island generally occurs bargaining between the processor and the steamer. This causes fish processors on Pasaran Island does not have a great bargaining position in determining the price. The largest processor share value is in the marketing channel from processor to small steamer with a share of $94.4 \%$ for nasi anchovy fish, $92.8 \%$ for buntiaw anchovy fish and $90 \%$ for jengki anchovy fish. The share value above $50 \%$ indicates that the performance of the industry, especially in marketing, can be said to be efficient. Therefore, the performance of anchovy fish processing industry cluster on Pasar Island can fall into the category of efficient in marketing channels from processors to small collectors. For marketing channels from processors to large collectors is still not efficient enough because the amount of revenue the processor receives is smaller than that of a large steamer.

The strategies formulated to optimize the performance of anchovy fish processing industry clusters on Pasar Island are divided into three substrategies including strategies in improving product quality, strategies in expanding markets and connections, and strategies in managing human resources on Pasaran Island.

\section{RECOMMENDATION}

For anchovy processing business owners, it is necessary to face changes in each of the actors in implementing these strategies. Furthermore, the first thing that needs to be done to business owners, especially each chairman of the processing and marketer groups, is in terms of administration, such as reregistering each member so that data on the processor can match each year, financial records and financial reports every year, as well as other administrations in terms of product quality certification., Processing SOP, PIRT, and halal label. In implementing this strategy, each actor also needs to get counseling about the changes that will be faced and the development of human resource skills on the island of Pasaran.

There is a need for well-targeted and sustainable guidance for anchovy processing business owners on Pasaran Island for the government. This guidance can be in the form of technology development assistance in the processing process. Apart from that, business assistance and training for Human Resources on Pasaran Island are also needed. The training needed by human resources on Pasaran Island includes training on product quality standards, product safety, MSME capital, financial records, and digital marketing for business owners and workers on Pasaran Island.

For further research, research can be carried out to analyze the strategy of strengthening the bargaining position owned by anchovy processors on Pasaran Island in order to break the existing bonded bonds chain gradually.

\section{ACKNOWLEDGMENT}

We would like to thank School of Business IPB University and all the respondents of our research for the opportunity that has been given to write this paper. 


\section{REFERENCES}

[1] Coordinating Ministry for Maritime Affairs and Investment of the Republic of Indonesia - Kementerian Koordinator Bidang Kemaritiman dan Investasi Republik Indonesia. 2018. Menko Maritim Luncurkan Data Rujukan Wilayah Kelautan Indonesia [Internet]. Available at: https://maritim.go.id/menko-maritimluncurkan-data-rujukan-wilayah-kelautan-indonesia/, 2018.

[2] [KKP] Kementerian Kelautan dan Perikanan Republik Indonesia. Peraturan Menteri Kelautan dan Perikanan Nomor 12/MEN/2010 tentang Pedoman Umum Minapolitan. Jakarta (ID), KKP, 2011.

[3] BW Ayu, RH Ismono, A. Soelaiman. "Analisis nilai tambah pada klaster industri pengolahan ikan teri kering di Pulau Pasaran Kota Bandar Lampung". Jurnal Ilmu Ilmu Agribisnis. 2013. 1(3):246-253,

[4] Harsono S. Analisis diskriminan kinerja industri pengolahan (Studi pada pengolahan ikan teri di Pulau Pasaran Kota Bandar Lampung) [skripsi]. Lampung (ID): Universitas Lampung, 2018.

[5] Porter ME. Competitive Advantage: Creating and Sustaining. 1985.

[6] WK Jaya. Ekonomi Industri; Konsep Dasar, Struktur, Perilaku dan Kinerja Pasar. Yogyakarta (ID): BPFE, 2001.

[7] Pearce JA, Robinson RB. Strategic Management: Formulation, Implementation and Control, 12th Edition. New York (US): McGraw Hill, 2011. 